\title{
DE
}

\section{THE GREAT POWERS AND THE ALBANIAN QUESTION: DYNAMICS OF THE EVOLUTION OF A RELATIONSHIP}

DOI: $10.2478 /$ seeur-2014-0017

The Albanian Question in a national and territorial context in the Balkans was born during the Eastern Crisis and was discussed during the Berlin Congress in 1881. The Albanian Question took its proper form when the other nations in the Balkans had already created their own states or were in the final processes of their creation.

The Albanians were violently forbidden by the Ottoman Empire to follow the road to autonomy and national independence. Their national question was ignored by the Great Powers of the time, which supported the first disection of Albanian territories in the Balkans in favour of the northern and the southern neighbouring kingdoms.

Albanian nationalism and its political platform for a national state did finally arrive. Its first manifestation, the Albanian League of Prizren, did not succeed. Thirty years later the Albanian National Movement had partially accomplished its historical mission, the independence proclamation and the creation of the national state. The proclamation took place in unfavourable European and Balkan circumstances. The "European Concert" had divided into two antagonist blocs, supporting the monarchies in the Balkans which had started a war against Turkey in order to force it leave the Balkans, and to annex territories which they claimed, including ethnic Albanian territories.

Essentially following the same logic as they had at the Berlin Congress, the Great Powers at the London Conference of Ambassadors (December 1912 - August 1913) intervened once again, dividing up territories principally in favour of the neighbouring states and recognizing an Albanian truncated state in the form of an autonomous principality, neutral and under their guarantee. This decision divided the Albanian nation into two parts. However Sir Edward 
Grey, the British Foreign Secretary, described the above as a scapegoat on the altar of European peace!

The Albanian Question was not the only issue which was not properly resolved at the London Conference of Ambassadors. The Treaty of 30 May 1913 between the warring states in the Balkans was imposed by force and further deepened the hostilities and the claims over territories that were not theirs. However the Albanian Question was registered in the mortgage office of the Balkans as the biggest pledge compared to the others for the future of the region. The entire 20th Century became a living and painful testimony of the heavy wounds caused by the imperialist surgery of the London Conference of Ambassadors on the body of the Albanian nation and its cohabitation with the neighbouring nations.

The fall of communism in Europe and the carving up of national multiethnical states violently built and sustained, created the potential opportunity to find a rational solution for the old unresolved national questions in the Balkans, based on the universal principle of the self-determination, as well as other principles internationally recognized as defined in the 1975 Helsinki and 1990 Paris Charters. However the demons of extreme nationalism denied the idea of freedom and national independence of people who were violently retained under the occupation of chauvanism for half a century. Therefore, in order to retain the violent and artificial multiethnic state constructions created and confirmed by the 1913 London Conference of Ambassadors, the 1919-1920 Paris Peace Conference and the 1945 Yalta Conference; they subjected Bosnians and Albanians to genocide and massive extermination as well as violated other ethnic communities claiming human rights protection.

Even during the 1990s some of the Great Powers still found it difficult to review their old clientelist politics in the Balkans. They hesitated to take action in order to impede Milosevic, Karadzic and Mladic, using force. The intervention of the United States of America in Bosnia- Hercegovina, and Kosova was decisive, not only for the Bosnians and the Albanians, but also for the democratic future of the whole region.

After the end of the war in Bosnia-Hercegovina in 1995, the Albanian Question neared the road of solution. The United States of America and a few European Powers understood that the stability, peace and security in the Balkans, were strongly linked to the ending of oppression and discrimination against the Albanians. For the first time in the 20th Century the majority of the Great Powers aimed to correct the decisions of the 1913 London Conference of Ambassadors with regard the Albanian question. I only talk 
about corrections because they were not and could not change in substance those decisions and could not provide the Albanians the opportunity to unify under the same state. For the first time in the 20th Century Albanian national fundamental interests in the Balkans were in line with the geostrategic interests of the United States of America and NATO in the Balkans. This community of interest led to further cooperation and to broader support expressed in the Rambouillet and Paris Conferences, through using force against the regime of Milosevic and obligating his regime to withdraw from Kosovo, thereby paving the way for its independence. The United States of America, the EU and NATO strongly supported the national rights of the Albanians in FYROM. This act of support paved the way for the signing of the Ohrid Agreement in August 2001.

Kosova's Independence in 2008 was the most important event in the entire history of the Albanian nation after the proclamation of the national independence in November 1912. The visible progress in the question of the Albanians' status in FYROM and Montenegro, as well as the often-raised "Cham question" has brought as a result, the growing importance of the Albanians as a factor in the Balkans. This situation has created positive emotions, pride and responsibility amongst Albanians. But not a few of them have raised hopes for national unity in the creation of a united Albanian state. Historical opponents of the Albanians, but also a good part of the politics and regional and international diplomacy during the last century have dubbed this approach as an attempt to create "Greater Albania".

This is an atavistic concept, which finds its origins in the chauvinistic platform of the Balkans of the 19th and 20th centuries. In reality there has never been an Albanian national platform for a "Greater Albania" as was the case in the Greek platform of Megali Idea, or Serbian Platform of Garashanin or other disciples of Serbian chauvinist nationalism up to Milosevic. In Albania and among the Albanians there has always been an articulated concern for historical injustice caused by London Conference of Ambassadors of 1913 which led to the dismemberment of Albanian lands and mistreatment suffered by their compatriots who were forced against their will to live in neighboring countries. Of course occasionally, even today, there are idealistical ideas expressed by politicians who voice their concern and seek national unity in an "Ethnic Albania", or a "natural Albania". Of course in democracy, everybody is entitled to use the fundamental freedom of expression, regardless of the fact that his or her ideas may not be shared by others. So there is nothing wrong with such discussions. The danger occurs when these ideas and views become the official platform and active policies 
of governments and states and when they are accompanied by concrete actions.

The Albanians are an important strategic element for equalibrium in the Balkans, not only for today but also in the future. Albania is a NATO member state and has achieved the status of a candidate country for EU membership. It has a particular strategic relationship with the United States once again strongly confirmed by the new Albanian government. Kosova is increasingly consolidating as an independent state and is internationally recognized. Direct negotiations with Serbia and the signature of concrete agreements between the two countries constitutes de facto recognition of Kosova's independence. Along with the dismemberment of Yugoslavia and the creation of independent states by the nations that broke away from her, it is the biggest geopolitical change that has occurred in the Balkans in the previous century.

The Balkans changed not only geopolitically, but also geostrategically. They are already guaranteeing security and are increasingly integrated into security structures, whether these are of a regional, European or international nature. They are no longer "the apple of discord" of the Great Powers, rather, most of the countries, if not all of them have succeeded in having a unified position on most of the conflicts and crisis produced in the two last decades coordinating policies and actions in search suitable solutions. The Balkans today are not the Great Powers' major priority because of the relative stability that exists as well as due to new conflicts and crises in other regions of the world, especially in the Middle East. It is not productive and a long-term goal when the focus is just to lick the wounds and to resolve conflicts. The focus should remain on serious development and integration projects that guarantee prosperity for the nations and understanding between them. There is much to do.

The lack of priority does not mean that the Great Powers have left the Balkans out of their agendas. They are present in different ways, political, economic and military. There is a status quo rather than a retreat. There is a change in the present club of Great Powers in the Balkans, some have lost their status, the weight and the role they had one hundred years ago, and others have maintained a presence of relative influence, mainly economic and political. The U.S. is the only real power, the greatest so far that broke the monopoly of the "European Concert" in the Balkans. They arrived and settled after World War II in the region more as containers of Soviet expansion, to become in the 90 's the country with a dominant influence in putting an end to the conflicts, restoring stability and guaranteeing security and regional peace. 
Four of the former Great Powers of the London Conference of one hundred years ago, are today the most prominent members of the European Union (Germany, Great Britain, France and Italy). Their presence and role in the Balkans as separate countries is of a relative importance in relation to the primary influence they exercise together and within the EU. EU leadership is widely accepted because it leads and currently monitors the process of European integration of the Western Balkans countries. The EU today is in a provocative sense the "European Concert" of the early 21st century, a modern collective body that still leads the Balkans until their institutional unification with the European family. While there are many indisputable differences between these two historical structures in time, organization, goals and content, I want to highlight one of them: the old rivalry has been replaced by unanimity and interaction to provide a secure European future for the nations of the region.

If in the geostrategy of the Balkans of the four European Powers, EU members, there is a fundamental difference compared to a century ago, what of the Russian geostrategic position in the Balkans? Putin's Russia today is obviously different in many aspects from the Russia of Tsar Nikolai II at the beginning of the previous century. But their goals in the Balkans have remained if not identical at least approximate. However, some instruments and methods have been upgraded or perfected over time. In the framework of Russia's foreign policy program adopted by President Putin in February 2013 it is noted that "the Balkan region" is of major strategical importance for Russia, including its role as a major center of transportation and infrastructure used to supply gas and oil to European countries.

This official document of Russian foreign policy highlights just one aspect of "great strategic importance" of the Balkans for Russia today. In addition, there are others that are not mentioned but implied, in particular political and military aspects. Historically, the focus of the Russian policy in the Balkans has been and remains the Slavic countries, especially Serbia. In these countries Russia is present with significant economic investments, has a traditional cultural presence and exerts significant political influence. Russia`s relationship with Serbia is complex and closer and does not exclude military cooperation and an alliance is obviously structured.

Serbia is experiencing the dilemma of reorientation. It has been offered the chance of EU and NATO integration but not without paying a price which begins with the Kosova issue, as well as a review of the strategic alliance with Russia. Belgrade might preserve the traditional ties with Russia, but should prioritize relations with the great centers of European and global policy, the EU, NATO and the U.S. However, there is a distinction to be made here. 
Serbia's political will is clearly expressed in relation to the Serbia's EU integration. But whether Serbia's relations with NATO are at the initial stage of cooperation or of an ambiguous nature, considering NATO's lack of a positive image among Serbian public opinion, remains a question.

Another important factor that tends to change the fragile geopolitical balances in the region of the Balkans is Turkey. The London Conference of one hundred years ago legitimized the decline of the Ottoman Empire by restricting it to the eastern edge of the Balkans. Today, Turkey having achieved the status of a regional power within the vast space around her, has strongly returned to the Balkans, aiming to enter into "the global game" played by the important actors in the international arena. Turkey has chosen as "its weapon" economic expansion and investments in strategic sectors of the region's countries, its natural presence in regional institutions of political and economic cooperation, as well as in regional and European security organizations. Further, Turkey is also involved with the preservation of old heritage and traditions, and regarding all-inclusive connections, the promotion and protection of the rights of the Turkish minorities, as well as the promotion and protection of the rights of the local populations of Muslims. The philosophical platform of this strategy is also one of the axes of Turkey's foreign policy which has been developed some years ago by the Turkish Foreign Minister Ahmet Davutoglu in the well-known book Strategic Depth.

It should be noted that Turkish strategy in the Balkans and beyond has contributed to stirring some "troubled waters" and some accuse Turkey "neoOttomanism". The Turkish prime minister`s statements in Prizren in Kosova, in October 2013, reinforced these charges. Most Albanians, due to historical Albanian-Turkish relations, as well as a cultural and common religious affinity and tradition, are more likely to accept the overall growth of the Turkish presence in the region. The official policies of Albania and Kosova have identified Turkey as a strategic partner. The reasons for such an important status can be found, not only in the historical or traditional context, but also in economic and geopolitical considerations.

Many people today seek the solution of the Albanian national question in terms of the classic model of past centuries, the unification of all Albanian territories in a united Balkan state. Is this a real possibility today? Not in my opinion. The Albanian Question will be resolved in the new context of the 21st century through the integration of all countries of the Western Balkans into the EU and NATO.

The geopolitical changes in the Balkans after the 1990's and the reconfiguration of the Albanian factor in the region, as well as the increase of 
its weight and its role within regional developments, are visible and tangible realities. These new realities should be addressed wisely by the Albanian political class in the region, without passion and emotion, and in cooperation with Albanian factors, bearing in mind the European common and integrated future. Any action taken should be guided by national interest, with a clear perspective, not one of a momentary nature, and particularly not one which serves the interests of a specific political segment. The final home of the Albanians is in a United Europe. This goal is "our guiding star" that should orient Albanians today and on their road towards the future. 


\section{$* * *$}

Paskal Milo is a historian, politician and leader of the Social Democracy Party of Albania. He finished postgraduate studies at Lund University Sweden. During his carrer he has worked as a journalist as well as he is a professor at several universities in Albania lecturing on Diplomatic History, Theory and Practice of Diplomacy and European Integration. His professional responsibilities include: Dean of the History and Philology Faculty Tirana University, Former State Secretary of Education, Foreign Affairs Minister and Minister of European Integration, Member of Albanian Parliament for 16 years. Milo is the author of several books on the diplomacy and foreign policy of Albania, Balkan history, Kosovo history and European Union history. One of his latest books is Politika e jashtme e Shqipërisë (2013). 


\section{Appendix 1}

\section{Final Program}

\begin{tabular}{|c|c|c|}
\hline Time & Topic & Speaker \\
\hline $\begin{array}{l}08: 30- \\
09 \cdot 00\end{array}$ & Registration & \\
\hline
\end{tabular}

\section{Opening Session}

\begin{tabular}{|l|l|l|}
\hline \multirow{4}{*}{$09: 00-$} & Welcome address & $\begin{array}{l}\text { Zamir Dika, Rector of the } \\
\text { South East European University }\end{array}$ \\
\cline { 2 - 3 } $09: 30$ & Welcome address & $\begin{array}{l}\text { Dennis Farrington, President of } \\
\text { the SEEU Board }\end{array}$ \\
\cline { 2 - 3 } & $\begin{array}{l}\text { Keynote speech: "The } \\
\text { Geopolitics of London }- \text { one } \\
\text { century later" }\end{array}$ & $\begin{array}{l}\text { Blerim Reka, Prorector for } \\
\text { Research and International } \\
\text { Relations SEEU }\end{array}$ \\
\cline { 2 - 3 } & $\begin{array}{l}\text { Greeting speech: "The role of } \\
\text { UK in the Balkans Peace" }\end{array}$ & $\begin{array}{l}\text { Christopher Yvon, H.E. The } \\
\text { Ambassador of UK in the } \\
\text { Republic of Macedonia }\end{array}$ \\
\hline
\end{tabular}

Working session I

Chair of the session: Blerim Reka, MK

\begin{tabular}{|l|l|l|}
\hline & $\begin{array}{l}\text { "Albanian Nationalism and the } \\
\text { London Conference of } \\
\text { Ambassadors" }\end{array}$ & $\begin{array}{l}\text { Bernd J. Fischer, USA, } \\
\text { Professor at Indiana University - }\end{array}$ \\
\hline
\end{tabular}




\begin{tabular}{|l|l|l|}
\hline \multirow{5}{*}{$\begin{array}{l}\text { 09:30- } \\
\text { 11:00 }\end{array}$} & $\begin{array}{l}\text { Purdue University Fort Wayne } \\
\text { (IPFW) }\end{array}$ \\
\cline { 2 - 3 } & $\begin{array}{l}\text { "Fuqitë e Mëdha dhe çështja } \\
\text { evolucionit." }\end{array}$ & Paskal Milo, AL, Former MFA \\
\cline { 2 - 3 } & $\begin{array}{l}\text { "Ideology and Bibliography : } \\
\text { The League of Nations and } \\
\text { Albania after 1923" }\end{array}$ & $\begin{array}{l}\text { James Pettifer, UK, Professor } \\
\text { at Oxford University History } \\
\text { Faculty }\end{array}$ \\
\cline { 2 - 3 } & $\begin{array}{l}\text { "Interesite na golemite sili i } \\
\text { sudbinata na Makedonija } \\
\text { (Londonskata ambasadorska } \\
\text { konferencija - kako povod)" }\end{array}$ & $\begin{array}{l}\text { Vlado Popovski, MK, Professor } \\
\text { at St. Cyril and Methodius, } \\
\text { Skopje }\end{array}$ \\
\cline { 2 - 3 } & $\begin{array}{l}\text { "The disunity of Great Powers } \\
\text { about Albanian issue and } \\
\text { the Final Settlement" }\end{array}$ & $\begin{array}{l}\text { Ibrahim Gashi, KS, Rector } \\
\text { University of Prishtina }\end{array}$ \\
\cline { 2 - 3 } & $\begin{array}{l}\text { "Qëndrimi i Bullgarisë ndaj } \\
\text { faktorit shqiptar në Maqedoni } \\
\text { gjatë Konferencës së Londrës" }\end{array}$ & $\begin{array}{l}\text { Anton Panchev, BG, Expert of } \\
\text { Balkanistic studies }\end{array}$ \\
\hline
\end{tabular}

\begin{tabular}{|l|l|}
\hline $11: 00-$ & Coffee Break \\
11:15 & \\
\hline
\end{tabular}




\section{Working session II}

Chair of the session: Charles Ingrao, USA

\begin{tabular}{|c|c|c|}
\hline \multirow{7}{*}{$\begin{array}{l}11: 15- \\
13: 00\end{array}$} & $\begin{array}{l}\text { "A Centennial Retrospective: } \\
\text { What Have We Learned?" }\end{array}$ & $\begin{array}{l}\text { Charles Ingrao, USA, } \\
\text { Professor at Purdue University }\end{array}$ \\
\hline & $\begin{array}{l}\text { "Trajtimi i çështjes shqiptare në } \\
\text { Konferencën e Ambasadorëve } \\
\text { në Londër dhe pasojat } \\
\text { gjeopolitike në Ballkan" }\end{array}$ & $\begin{array}{l}\text { Fejzulla Shabani, MK, } \\
\text { Professor at SUT \& SEEU }\end{array}$ \\
\hline & $\begin{array}{l}\text { "Konferenca e ambasadoreve ne } \\
\text { Londer } 1913 \text { e ndau ne dysh } \\
\text { popullin shqiptar" }\end{array}$ & $\begin{array}{l}\text { Xheladin Shala, KS, The } \\
\text { Institute of Albanology, } \\
\text { Prishtina }\end{array}$ \\
\hline & $\begin{array}{l}\text { "In anticipating the London } \\
\text { Conference - why and to what } \\
\text { extent did the governments of } \\
\text { Greece and Serbia seek to } \\
\text { prevent the emergence of the } \\
\text { Albanian State." }\end{array}$ & $\begin{array}{l}\text { Miranda Vickers, UK, British } \\
\text { writer and analyst of Albanian } \\
\text { affairs }\end{array}$ \\
\hline & $\begin{array}{l}\text { "Uillsoni dhe Politika Europiane } \\
\text { në Shqipëri 1918-1920" }\end{array}$ & $\begin{array}{l}\text { Lavdosh Ahmetaj, AL, Rektor } \\
\text { i Universitetit "Pavarësia"- } \\
\text { Vlorë \& Arsim Sinani, MK, } \\
\text { PhD cand., University of Tirana }\end{array}$ \\
\hline & $\begin{array}{l}\text { "Answering the wrong question: } \\
100 \text { years of misreading the } \\
\text { Balkans" }\end{array}$ & $\begin{array}{l}\text { Robert Wilton, UK, Head of } \\
\text { OSCE Mission, Albania }\end{array}$ \\
\hline & $\begin{array}{l}\text { "Albanskoto Nacionalno } \\
\text { Prashanje vo Svetlinata na } \\
\text { Londonskata Mirovna } \\
\text { Konferencija" }\end{array}$ & $\begin{array}{l}\text { Branislav Sinadinovski, MK, } \\
\text { Professor }\end{array}$ \\
\hline
\end{tabular}

\section{3:00 - Lunch (Speakers and VIP guests) \\ 14:30 \\ Working session III}

Chair of the session: Fejzulla Shabani, MK

\begin{tabular}{|l|l|l|}
\hline & $\begin{array}{l}\text { "Konferenca e Paqes në Paris si } \\
\text { vazhdim i Konferencës së } \\
\text { Ambasadorëve në Londër dhe } \\
\text { Çështja e Shqiptarëve" }\end{array}$ & $\begin{array}{l}\text { Izber Hoti, KS, Institute of } \\
\text { History “Ali Hadri”, Prishtina }\end{array}$ \\
\cline { 2 - 3 } & $\begin{array}{l}\text { "European Security Potential in } \\
\text { the Region of the Western }\end{array}$ & $\begin{array}{l}\text { Ida Orzechowska, PL, } \\
\text { University of Wroclaw }\end{array}$ \\
\hline
\end{tabular}




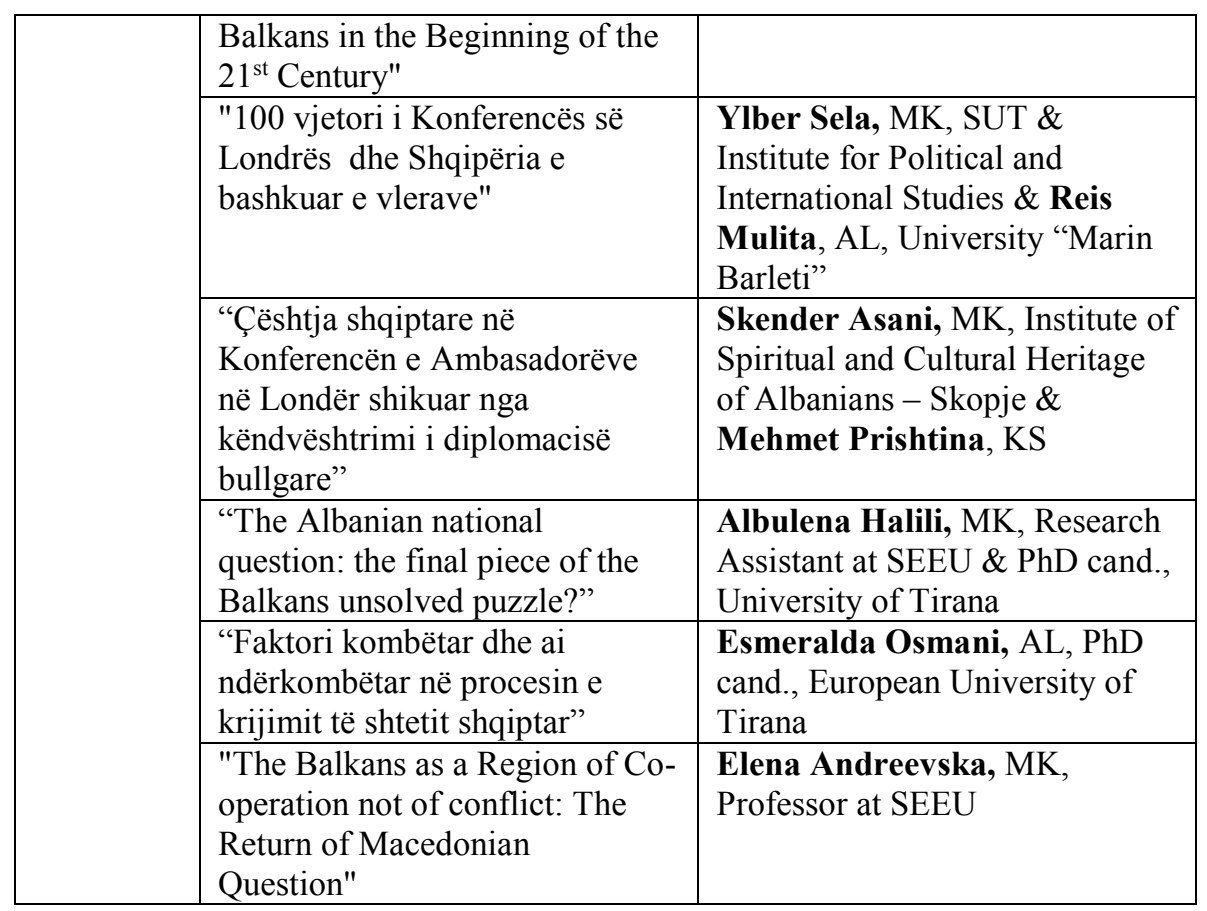




\begin{tabular}{|l|l|l|}
\hline $\begin{array}{l}\text { "Shqipëria nga Konferenca e } \\
\text { Ambasadorëve në Londër 1913 } \\
\text { në Konferencën e Paqes në Paris } \\
\text { 1919. Skicat gjeopolitike të } \\
\text { çështjes shqiptare dhe disa } \\
\text { konfigurime dhe sfida aktuale" }\end{array}$ & $\begin{array}{l}\text { Romeo Gurakuqi, AL, } \\
\text { Professor at European } \\
\text { University of Tirana }\end{array}$ \\
\cline { 2 - 3 } "Anulimi i Londrës 1913- \\
$\begin{array}{l}\text { domosdoshmëri për një paqe të } \\
\text { qëndrueshme në rajon" }\end{array}$ & $\begin{array}{l}\text { Koço Danaj, AL, Director of } \\
\text { the Center of Political and } \\
\text { Social Prognosis in Tirana }\end{array}$ \\
\cline { 2 - 3 } "Pozita juridiko-ndërkombëtare \\
e Shqipërisë pas Konferencës së \\
$\begin{array}{l}\text { Ambasadorëve deri në mbarim } \\
\text { të Luftës së Parë Botërore" }\end{array}$ & $\begin{array}{l}\text { Krofofon Kror at European } \\
\text { University of Tirana }\end{array}$ \\
\cline { 2 - 3 } "Kosova dhe Maqedonia - akti i \\
fundit i Krizës Lindore?" & Jusuf Buxhovi, KS, historian \\
\hline
\end{tabular}

\begin{tabular}{|l|l|}
\hline $\begin{array}{l}\text { 15:15 - } \\
15: 30\end{array}$ & Coffee Break \\
\hline
\end{tabular}

\begin{tabular}{|l|l|}
\hline $15: 30-$ & Discussion \\
$16: 00$ & \\
\hline
\end{tabular}

\begin{tabular}{|l|l|}
\hline $16: 00-$ & Concluding remarks \& Adjourn \\
$16: 10$ & \\
\hline
\end{tabular}


SEEU Review | Special Edition | Volume 10 | Issue 1 | 2014 


\section{Appendix 2}

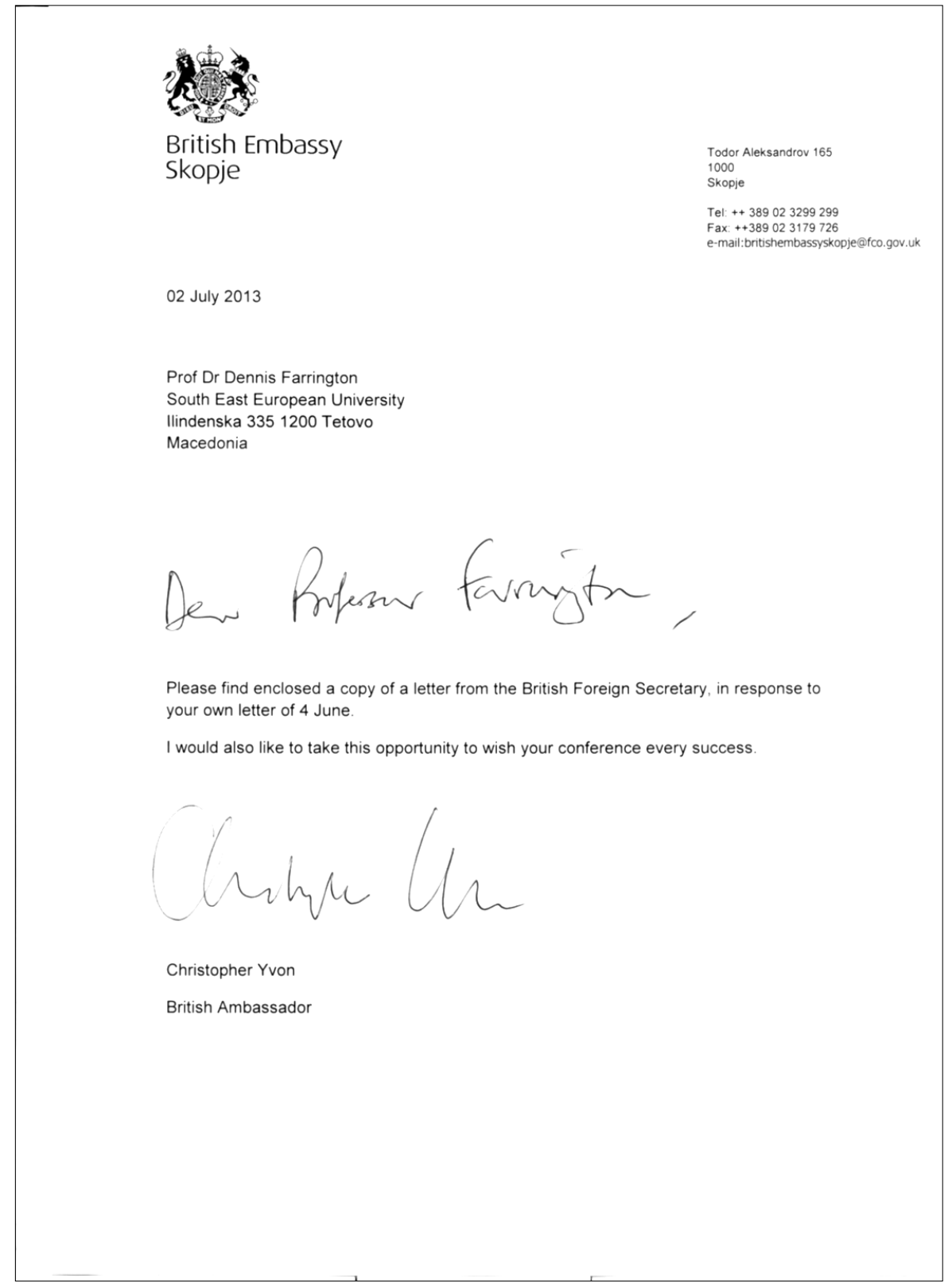


June 2013

Prof Dr Dennis Farrington

South East European University

Ilindenska 335

1200 TETOVO

Macedonia

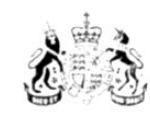

Foreign \& Commonwealth Office

1.onden SW11:-1H trom the serretnn of stat

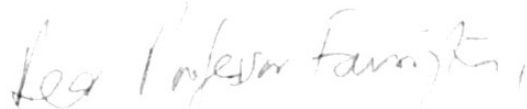

Thank you for your letter of 4 .June inviting me to speak at your conference in November, commemorating 100 years since the London Peace Conference in 1913.

Regrettably, I must decline your invitation on this occasion. I wish you all the best for the event, which I am sure will be an interesting analysis of the changing face of a fascinating region.

WILLLAM HAGUE 

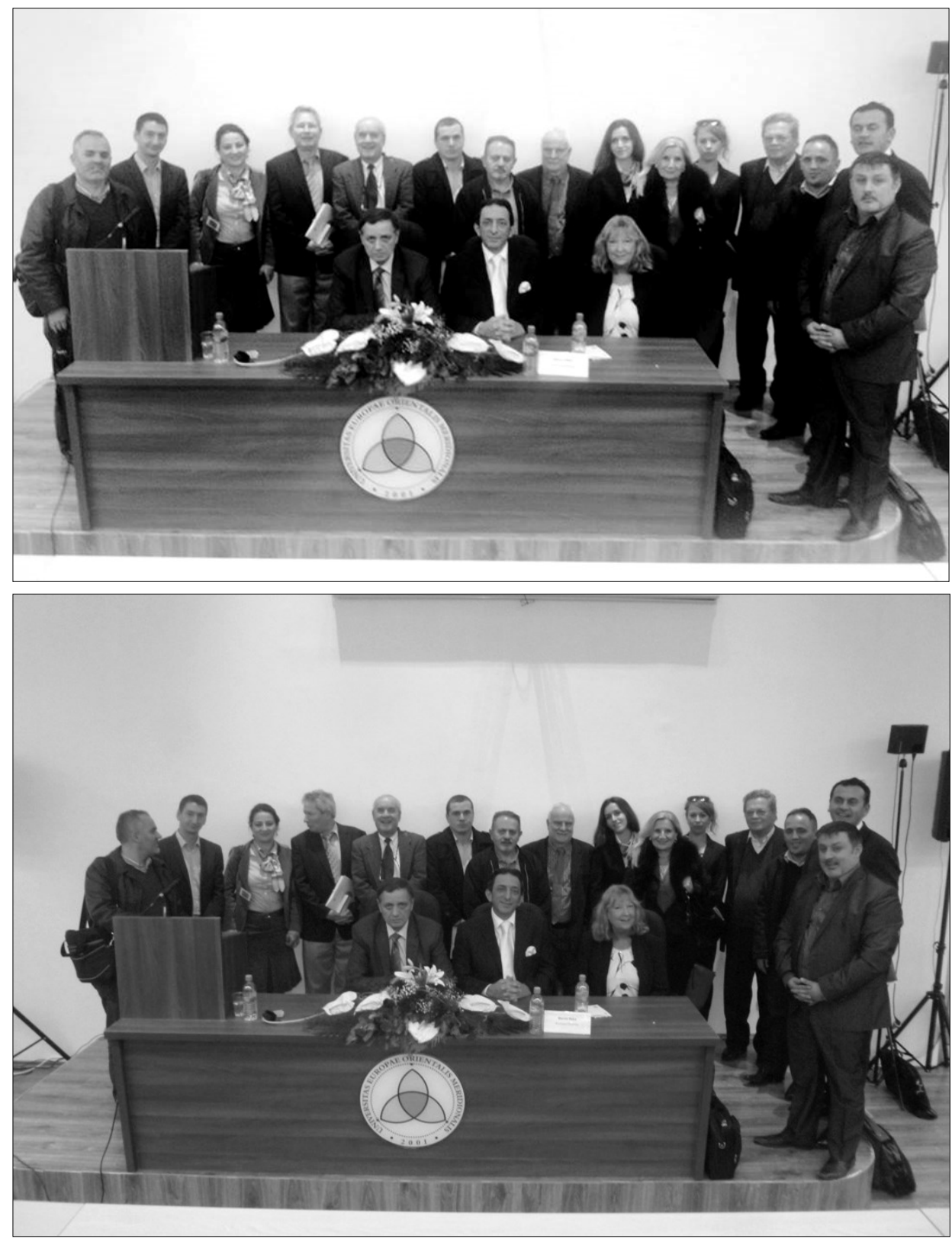